\title{
Prediction of Coronary Artery Disease Among Chronic Hepatitis C Virus Infected Patients in Tamilnadu, India
}

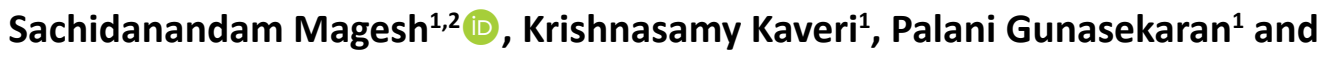 \\ Karuppanan Sathiyamurthy ${ }^{2 *}$
}

${ }^{1}$ Department of Virology, King Institute of Preventive Medicine and Research, Chennai - 600 032, Tamilnadu, India. ${ }^{2}$ Department of Biomedical Science, School of Basic Medical Sciences, Bharathidasan University, Trichy 620 024, Tamilnadu, India.

\begin{abstract}
C-reactive protein (CRP) in the form of high sensitivity CRP (hs-CRP) is one of the better extensively used risk marker for the coronary artery disease (CAD) in clinical practice. Increased value of hs-CRP has been related with increased threat for the development of blood pressure, stroke, peripheral arterial disease, temporary ischemic attack and sudden coronary deceased condition. If hs-CRP involves a fundamental role in atherothrombosis, then hs-CRP is the better biomarker proposed to be necessary for improving to detect the risk of coronary events of arterial disease. In this study, the HCV seropositive patients (by Anti HCV-IgG Indirect Elisa) more than 2 years old, hepatic and leukaemia were investigated for extra hepatic manifestation. The Lab request forms with questionnaire were together including CRP, HS-CRP, serum cholesterol and liver function tests were scrutinized. Total of $\mathbf{1 7 0}$ cases (around the Chennai) was taken for the study. In which, $\mathbf{4 5 . 3 \%}$ of cases were observed as hepatitis patients with ALL cases. The other $8 \%$ of cases were having liver cirrhosis and rest of the cases was not having cirrhosis. Finally, the study explores the relationship between the HCV seropositive of leukaemia cases, HCV RNA and CRP, hs CRP with cirrhosis. These evaluations point out that HCV infection may amend the chronic inflammatory condition in leukaemia patients. Additionally, the results recommended that screening for hs-CRP should be considered previous to evaluation of cardiovascular risk in HCV patients, because the results may affect the risk scoring of coronary artery disease.
\end{abstract}

Keywords: Hepatitis C Virus, Coronary artery disease (CAD), hs-CRP, Leukaemia.

*Correspondence: ksathiyamurthy@yahoo.com; 9444581708

(Received: 06 August 2019; accepted: 08 September 2019)

Citation: Sachidanandam Magesh, Krishnasamy Kaveri, Palani Gunasekaran and Karuppanan Sathiyamurthy, Prediction of Coronary Artery Disease Among Chronic Hepatitis C Virus Infected Patients in Tamilnadu, India, J Pure Appl Microbiol., 2019; 13(3): 15551560. https://doi.org/10.22207/JPAM.13.3.28

C The Author(s) 2019. Open Access. This article is distributed under the terms of the Creative Commons Attribution 4.0 International License which permits unrestricted use, sharing, distribution, and reproduction in any medium, provided you give appropriate credit to the original author(s) and the source, provide a link to the Creative Commons license, and indicate if changes were made. 


\section{INTRODUCTION}

Hepatitis C virus RNA (HCV RNA) is the most significant indicator of viral replication in hepatitis $C$ infected patients. By using polymerase chain reaction (PCR) method, HCV RNA is significant parameter in the detection of viremia in serum or plasma can be qualitatively or quantitatively detected, indicates the infection level and the efficiency of treatment ${ }^{1,2}$. C-reactive protein (CRP) is secreted from the liver and belongs to main acute-phase protein, which is the mediator to produce tissue damage and activates the complement system. In humans, after the acute inflammatory stimuli thousand-fold or more levels of fibrogenic activity is markedly noted in the plasma ${ }^{3}$ and increased level of production by hepatocytes ${ }^{4}$.

In the googling related to this study, few past studies reviewed that investigating the correlation between the presence of antibody against hepatitis $C$ virus and point of CRP particularly in dialysis patient sera. High sensitive level of C-reactive protein (hs-CRP) is one of the better factor analyses hopefully in the laboratory to determine the micro inflammatory condition and their concentration. The determination of CRP level helps to distinguish individuals with a raised atherothrombotic risk and as well as direct pathogenetic role ${ }^{5}$.

In previous studies, CRP is the major systemic indicator of inflammation, induce adhesion molecule expressed in human endothelial cells and supporting involvement of CRP in the progression of atherosclerotic condition. Previously used analysing methods were unsatisfactorily sensitive to measure the level of CRP in blood less than the normal range that is below $10 \mathrm{mg} / \mathrm{L}$ and at the same time the current development of high-sensitive analysis for CRP (hs-CRP) has allowed to detect even slightly elevated level of CRP when compare with the normal range. Now a day, entirely automated and reliable high-sensitive analysing methods for CRP are now available worldwide. The previous reports revealed the direct reciprocal association between hs-CRP and future coronary disease relevant ${ }^{6}$.

Locasciulli et al. ${ }^{7}$ determined that prevalence of HCV infection in a large cohort study in which patients recovered from childhood leukaemia and followed potentially for liver disease from at least ten years as withdrawal of chemotherapy. The target of this study to differentiate from the other studies, was to decide if the range of hs-CRP concealed from the liver differed based on the positive or negative of the HCV RNA in sera or plasma collected from infected patients (who were suffered from leukaemia) of everyone with HCV IgG antibodies.

\section{MATERIALS AND METHODS}

\section{Patient's sample selection}

A total of one hundred and seventy patients with clinically suspected Hepatitis C infection were incorporated in this study, in which anti-HCV IgG antibodies was detected to be positive and who were referred to the institutional virology department for the analysis of viral markers.

IgG antibodies against Hepatitis C infection were detected by Microlisa (J. Mitra, India) and HCV RNA were identified by Nested $\mathrm{PCR}^{8,9}$. Sera with HCV RNA of above 1000 copies/ $\mathrm{ml}$ were appraised as positive of HCV RNA level.

\section{Exclusion criteria}

Patients with liver disease based on alfa fetoprotein (> $400 \mathrm{ng} / \mathrm{mL}$ ) and transabdominal ultrasound or treatment with like non steroid antiinflammatory drugs which could interfere with the hs-CRP results, were disqualified from the study. HS-CRP Analysis

The hs-CRP levels (Normal result: $<1.0$ $\mathrm{mg} / \mathrm{L}$ ) of the anti-HCV positive patients were detected in a Hitachi 902 analyser by based on the principle of particle enhanced immune turbidimetric method.

\section{Group selection}

In this study, the total of one hundred and seventy anti-HCV IgG positive samples were classified in to two groups based on the HCV RNA analysis, as the positive of HCV RNA (which have 41 samples under Group 1) and the negative of HCV RNA ( which have 129 samples under Group 2).

\section{Ethical consideration}

The local ethical committee at the institute approved the common project protocols and complete details of aetiology in written concern form and oral approval were received from all patients and recorded. 


\section{Statistical analysis}

Comparison of the quantitative mean values of the cumulative hs-CRP results of Group 1 and 2 were performed by student's t test. The numerical rates of the hs-CRP positive results comparison and related to both groups were analysed by using proportion test. Statistically $P$-value of $<0.05$ was considered as significant difference.

\section{RESULTS}

Since in this study, the hs-CRP values occurred to above the normal level in 14 (34.14\%) of the 41 sera samples in the first group and in $15(11.62 \%)$ of the 129 sera samples in the second group, numerical comparison of the hsCRP positive samples released as a statistically significant result in favour of group $1(P<0.001)$ designated in Fig. 1. At the same time when compared with two groups of each other, the mean value results of the quantitative hs-CRP were found statistically insignificant ( $P>0.05)$ condition.

Among the demographic data and symptom wise distribution of HCV cases (Table 1), group 1 patients displayed a distinct data level of atherogenic condition, as indicated by 11 (26.83\%) patients were diabetic, 18 (43.90\%) arterial hypertension, 2 (4.87\%) smoking, 15 (36.58\%) leukaemia, 6 (14.63\%) vascular thrombosis, $3(7.32 \%)$ cardiac ischemia and 17 (41.46\%) unknown cases. We also found in the group 1 patients that increased levels of Total Cholesterol
Table 1. Demographic data and Symptoms wise distribution of HCV cases

\begin{tabular}{llcc}
\hline No. & $\begin{array}{l}\text { Case study and } \\
\text { Symptoms }\end{array}$ & $\begin{array}{c}\text { HCV RNA } \\
\text { Positive }\end{array}$ & $\begin{array}{c}\text { HCV RNA } \\
\text { Negative }\end{array}$ \\
\hline 1. & $\begin{array}{l}\text { Number of } \\
\text { samples }\end{array}$ & 41 & 129 \\
2. & $\begin{array}{l}\text { Sex (Male/ } \\
\text { Female) }\end{array}$ & $22 / 19$ & $72 / 57$ \\
3. & Age & $42.5 \pm 16.5$ & $45.6 \pm 15.6$ \\
4. & $\begin{array}{l}\text { Diabetes } \\
\text { 5. }\end{array}$ & $11(26.83 \%)$ & $37(28.68 \%)$ \\
6. & $\begin{array}{l}\text { Smortension } \\
\text { Leukaemia }\end{array}$ & $18(43.90 \%)$ & $52(40.31 \%)$ \\
cases & $15(4.87 \%)$ & $13(10.08 \%)$ \\
8. & $\begin{array}{l}\text { Vascular } \\
\text { thrombosis }\end{array}$ & $6(14.63 \%)$ & $13(10.08 \%)$ \\
9 & $\begin{array}{l}\text { Cardiac } \\
\text { ischemia }\end{array}$ & $3(7.32 \%)$ & $8(6.20 \%)$ \\
10. & Unknown & $17(41.46 \%)$ & $46(35.66 \%)$
\end{tabular}

(TC), Triglycerides (TGL), HDL-C, CRP, hs-CRP and lower concentrations of LDL-C in which the significant difference was noted. The biochemical marker wise distribution of HCV cases was denoted in Table 2.

The HCV RNA negative patients (group 2) included that 37 (28.68\%) diabetic conditions, 52 (40.31\%) with arterial hypertension, 13 (10.08\%) vascular thrombosis, 62 (48.06\%) leukaemia, $8(6.20 \%)$ cardiac ischemia and 46 (35.66\%) unknown cases. In the group 1 category, similar to that of biological disorders from HCV RNA negative

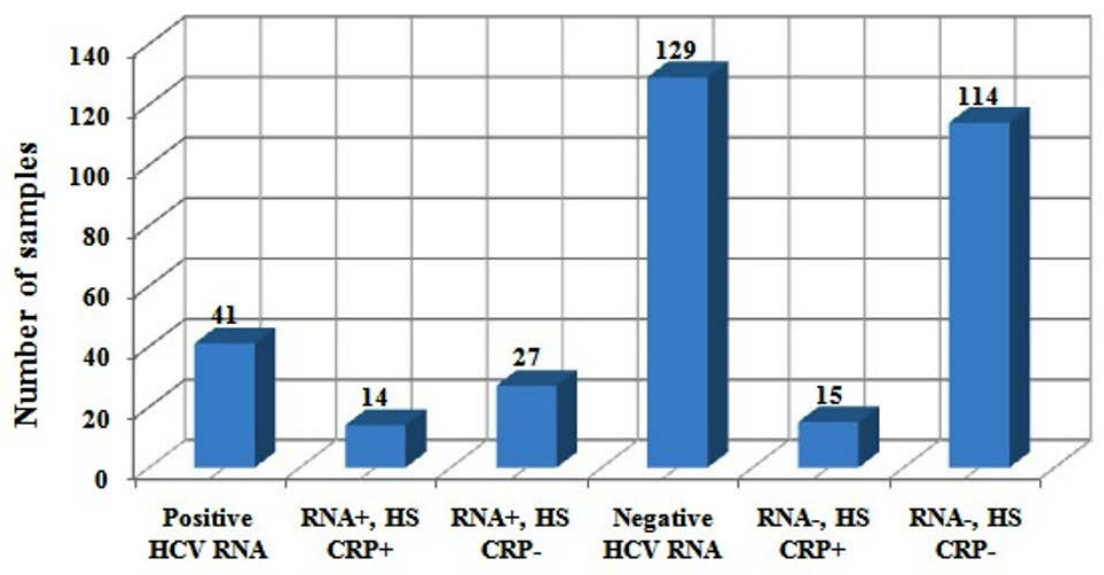

Fig. 1. Correlation between HCV RNA and hs-CRP analysis. 
Table 2. Biochemical markers wise distribution of total HCV cases

\begin{tabular}{llcc}
\hline No. Biochemical & HCV RNA & HCV RNA \\
porameters & $\begin{array}{c}\text { Positive } \\
\text { patients } \\
(\mathrm{n}=41)\end{array}$ & $\begin{array}{c}\text { Negative } \\
\text { patients } \\
(\mathrm{n}=129)\end{array}$ \\
\hline 1. & $\mathrm{TC}(\mathrm{mmol} / \mathrm{L})$ & $280 \pm 30.0$ & $260 \pm 26.0$ \\
2. & $\mathrm{HDL}-\mathrm{C}(\mathrm{mg} / \mathrm{dL})$ & $48 \pm 6.5$ & $42 \pm 8.5$ \\
3. & $\mathrm{LDL}-\mathrm{C}(\mathrm{mg} / \mathrm{dL})$ & $60 \pm 12.0$ & $82 \pm 5.2$ \\
4. & $\mathrm{TGL}(\mathrm{mg} / \mathrm{dL})$ & $240 \pm 22.0$ & $180 \pm 32$ \\
5. & Albumin $(\mathrm{mg} / \mathrm{dL})$ & $3.2 \pm 0.8$ & $3.8 \pm 0.3$ \\
6. & $\mathrm{CRP}(\mathrm{mg} / \mathrm{L})$ & $4.2(1.0-20.5)$ & $3.2(1.0-18.2)$ \\
7. & Hs-CRP $(\mathrm{mg} / \mathrm{L})$ & $5.6(0.5-22.5)$ & $3.0(0.5-19.6)$ \\
\hline
\end{tabular}

$\mathrm{mmol} / \mathrm{L}$ : millimole per Liter, $\mathrm{mg} / \mathrm{dL}$ : milligrams per DeciLiter, $\mathrm{mg} / \mathrm{L}$ : milligrams per Liter

patients were observed. The group 2 patients had a significant difference in the range of albumin, TC, HDL-C and TGL. According to HCV RNA positive patients, HCV RNA negative patients coming under the significant increased $(P<0.001)$ concentration of LDL-C.

\section{DISCUSSION}

CRP has a $115 \mathrm{kDa}$ molecular weight with pentamer structure. The physiological activity of CRP has not been explained accurately, but it may not only act as authorised factor for endotoxins but also for opsonized bacterial byproducts ${ }^{10}$. When compared with healthy controls, the serum levels in haemodialysis patients are ten-fold higher and numerous factors presently are discussed as targeting to this prominent inflammatory response. The process may not only called as microinflammation but also tolerate an underlying infectious stimulus.

Although new and recent spectacular information on the analysing power of CRP, couple of the kidney failure patients and in general population, several queries are unpredicted. Now a day, CRP emerged as a very important biomarker to diagnosis clinically for asymptomatic conditions. This marker is very sensitive, efficient and reliable to detect the risk of vascular changes at early stage in healthy individuals and give details about usage of high-sensitivity assays (normal range $<5 \mathrm{mg} / \mathrm{L}$ ) in most of the laboratories. Actually, this normal range is not considered as 'normal' values while some individuals have same values apparent that even $<5 \mathrm{mg} / \mathrm{L}$ of CRP concentrations in atherothrombotic condition or prone to disease development ${ }^{11,12}$.

The necro-inflammatory condition of the liver leads to hepatitis caused by various hepatotropic viruses. Regarding the viral hepatitis agents and in the chronic stage of the disease, cytokines are the important factors for immune response initiation against them. Proinflammatory cytokines for example IL-1, IL-3 and TNF-alpha are generated in the Kupffer cells of the liver. The increased this type of cytokines secretion is directly proportional to the increased release of the acute phase level proteins from the liver cells. The streaming and non-circulating cells are secreted the cytokine IL- 6 in the plasma leads to production of CRP, an acute phase protein from the liver. We aimed in this study from the anti-HCV IgG positive samples, those who had viremic groups with either HCV positive or negative to detect the CRP secreted from the liver.

HCV RNA negative patients had a considerable increased concentration of LDL-C when compared with HCV RNA positive patients indicated that CRP could enhance the uptake of native LDL in to macrophages. Regarding the current study, the insignificance of the statistical level was detected when the quantitative average values of hs-CRP were evaluated between both the group either positive $(n=41)$ or negative of $\mathrm{HCV}$ RNA ( $n=129)$.

During the literature collection for our study, the interesting point is that similar results observed in a couple of separate studies in haemodialysis patients. In both studies, the higher level of CRP values are detected in the hepatitis $C$ antibody negative group when compared with the group have positive condition for the same hepatitis C antibody ${ }^{13,2}$. Romania in 1995, reported that the earlier results are associated with the subjects of CRP level. The investigators observed that 5 (12.19\%) patients have a higher level of CRP than the normal level, out of the 41 sera positive for anti-HCV in haemodialysis patients ${ }^{14}$.

Gedik et al. ${ }^{15}$ explained that the relationship between hs-CRP rates and hepatitis $B$ viral load were unclear, in a previous study. Rifai et al. ${ }^{16}$ hope and urge that the FDA will instruct the clinical chemistry community regarding the importance of hsCRP values in cardiovascular 
disease evaluation. The very important confusion about the hsCRP, the clinicians and practicing physicians should know the variation between older and the newer methods of CRP and hsCRP estimation for the detection of a cardiovascular risk condition.

The main motivation of our study, differing from the other studies on hepatitis $C$ infection mentioned above was investigation of the hs-CRP levels between viremic groups who have positive of hepatitis $C \lg G$ antibody and positive for HCV RNA, whereas non viremic groups means as HCV RNA negative. As a significance of the data presented in this study, even though it is difficult to come a crystal clear conclusion with about the correlation between certain serological indicators and hepatitis $C$ virus infected patients containing hs-CRP, we believed that our results are valuable presenting for it and will support the issue to be investigated broadly and in more aspects.

\section{ACKNOWLEDGMENTS}

We would like thank to Indian Council of Medical Research (ICMR), Government of India for supporting the laboratory in Department of Virology, King Institute of Preventive Medicine and Research, Guindy, Chennai and the laboratory staff for their support throughout the study.

\section{CONFLICTS OF INTEREST}

The authors declares that there is no conflict of interest.

\section{AUTHORS' CONTRIBUTION}

$S M, K K, P G$ and $K S$ designed the experiments. SM and KK performed the experiments. SM, KK and KS analyzed the data and wrote the manuscript. PG and KS supervised and reviewed the manuscript. SM, KK, PG and KS read and approved the manuscript.

\section{FUNDING}

None.

\section{DATA AVAILABILITY}

All datasets generated or analyzed during this study are included in the manuscript.

\section{ETHICS STATEMENT}

Ethical clearance was obtained from institutional ethical committee.

\section{REFERENCES}

1. Henderson, D.K. Managing occupational risks for hepatitis $C$ transmission in the health care setting. Clinical Microbiology Reviews, 2003; 16(3): 546-568. https://doi.org/10.1128/CMR.16.3.546568.2003

2. Özekinci, T., Atmaca, S. and Akbayin, H. Correlation of high sensitive $\mathrm{C}$-reactive protein and Hepatitis C Virus RNA in anti-HCV-positive sera/Anti-HCV pozitif serumda yuksek duyarlikli C-reaktif protein ve Hepatit C virus RNA iliskisi. Dicle. Tip. Dergisi., 2011; 38(2): 134. https://doi.org/10.5798/ diclemedj.0921.2011.02.0002

3. Ablij, H.C., and Meinders, A.E. C-reactive protein: history and revival. European Journal of Internal Medicine, 2002; 13(7): 412-422. https://doi. org/10.1016/S0953-6205(02)00132-2

4. Volanakis J.E. Human C-Reactive protein: expression, structure and function. Mol. Immunol. 2001; 38(2): 18997. https://doi.org/10.1016/S0161-5890(01)00042-6

5. Rogowski, O., Vered, Y., Shapira, I., Hirsh, M., Zakut, $\mathrm{V}$. and Berliner, S. Introducing the wide range C-reactive protein (wr-CRP) into clinical use for the detection of microinflammation. Clinica Chimica Acta., 2005; 358(1-2): 151-158. https://doi.org/10.1016/j. cccn.2005.02.024

6. Helal, I., Zerelli, L., Krid, M., ElYounsi, F., Maiz, H. B., Zouari, B., et al. Comparison of C-reactive protein and high-sensitivity C-reactive protein levels in patients on hemodialysis. Saudi Journal of Kidney Diseases and Transplantation, 2012; 23(3): 477.

7. Locasciulli, A., Testa, M., Pontisso, P., Benvegnù, L., Fraschini, D., Corbetta, A., et al. Prevalence and natural history of hepatitis $C$ infection in patients cured of childhood leukemia. Blood, 1997; 90(11): 4628-4633. Ohno, O., Mizokami, M., Wu, R. R., Saleh, M. G., Ohba, K., Orito, E., et al. New hepatitis C virus (HCV) genotyping system that allows for identification of $\mathrm{HCV}$ genotypes 1a, 1b, 2a, 2b, 3a, 3b, 4, 5a, and 6a. Journal of Clinical Microbiology, 1997; 35(1): 201-207.

9. Magesh, S., Bupesh, G., Sathiyamurthy, K., Saran, N., Vennila, S., Sureshbabu, B.V., et al. Seroprevalence, Epidemiology and Genetic Characterization of Hepatitis C Virus, India. Virol. Immunol. J., 2016; 1(1): 000102. https://doi.org/10.23880/VIJ-16000102

10. Ertem, A. G., Efe, T. H., Yayla, C., Akboga, M. K., An ar, B., Ünal, S., et al. The association between serum procalcitonin levels and severity of coronary artery disease assessed by SYNTAX score in patients with acute coronary syndrome. Angiology, 2017; 68(1): 40-45. https://doi.org/10.1177/0003319716638239

11. Ridker, P.M. Cardiology Patient Page. C-reactive protein: a simple test to help predict risk of heart attack and stroke. Circulation, 2003; 108: e81-e85. https:// doi.org/10.1161/01.CIR.0000093381.57779.67 
12. Pascoe, M.C., Thompson, D.R., Jenkins, Z.M. and Ski, C.F. Mindfulness mediates the physiological markers of stress: Systematic review and meta-analysis. Journal of psychiatric research, 2017; 95: 156-178. https://doi. org/10.1016/j.jpsychires.2017.08.004

13. Stevens, L. A., Adhikarla, R., Mukkapati, P., Rahmati, M., Kaysen, G. A. and Levin, N. W. The impact of HCV positive status on mortality and CRP levels in incident hemodialysis patients. In Journal of the American Society of Nephrology, 2002; 13: 223-227.

14. Santos, C. A., Antonello, V. S. and Antonello, I. C. F. An Assay: Hepatitis C Doesn't Incite Increased C-Reactive Protein Level in Hemodialysis Patients Unless another Inflammatory Condition is Associated. Journal of Gastroenterology and Hepatology Research, 2017; 6(4): 2416-2418. https://doi.org/10.17554/j. issn.2224-3992.2017.06.719

15. Gedik, M., Ozekinci, T., Ozbek, E., Yilmaz, S. and Atmaca, S. Lack of correlation between CRP and hepatitis $B$ viral load in serum of patients with chronic HBV. Journal of Infection, 2007; 54(2): 204. https://doi. org/10.1016/j.jinf.2006.04.009

16. Rifai, N., Ballantyne, C. M., Cushman, M., Levy, D. and Myers, G. L. Point: high-sensitivity C-reactive protein and cardiac C-reactive protein assays: is there a need to differentiate? Clinical Chemistry, 2006; 52(7): 12541256. https://doi.org/10.1373/clinchem.2006.070904 